\title{
CARBON STORAGE IN EUCALYPTUS AND PINE PLANTATIONS IN SOUTH AFRICA
}

\author{
S.I. CHRISTIE ${ }^{1}$ and R.J. SCHOLES ${ }^{2}$
}

\author{
${ }^{\prime}$ Division of Forest Science and Technology, CSIR, Private Bag X11227, Nelspruit 1200, \\ South Africa. ${ }^{2}$ Division of Forest Science and Technology, CSIR, P.O. Box 395, Pretoria 0001, \\ South Africa.
}

\begin{abstract}
Carbon (C) is stored by plantation forests either when ecosystems with a low C density (such as tropical grasslands) are afforested or when timber is converted to semipermanent products. If the afforestation rate is relatively constant and the plantations are not harvested immediately upon reaching maturity, the amount of $\mathrm{C}$ stored in trees as a result of afforestation can be calculated by a simple "static" approximation. Rotation forestry requires a mean $C$ storage method that averages $C$ density over the rotation. Plantation forestry as practiced in South Africa requires a more detailed dynamic approach that accounts for time-varying rates of afforestation and the age-dependence of $\mathrm{C}$ accumulation rates in plantations. To determine $\mathrm{C}$ storage in products, the output of long-lived plantation products and their $\mathrm{C}$ content once all processing losses are accounted for must be known. The South African case study shows that new afforestation stored approximately $2.54 \mathrm{Tg} \mathrm{C}$ in 1990 , and storage in forest products accounted for an additional $1.15 \mathrm{Tg} \mathrm{C}$. Together, these two activities offset approximately $3.8 \%$ of the carbon dioxide emissions from South Africa.
\end{abstract}

\section{Introduction}

Carbon dioxide $\left(\mathrm{CO}_{2}\right)$ that is removed from the atmosphere and stored as carbon (C) may be considered to be sequestered in terms of the United Nations Framework Convention on Climate Change, and can be offset against the $\mathrm{CO}_{2}$ emissions for that country. One mechanism of $\mathrm{C}$ storage is through its assimilation in vegetation. Numerous authors have estimated the potential of forests and agroforestry management practices to store C (Dixon et al., 1994; Harmon et al., 1990; Schroeder, 1992; and Winjum et al., 1992).

When an ecosystem with a low $\mathrm{C}$ density (the amount of organic $\mathrm{C}$ per unit of land area, in $\mathrm{Mg} \mathrm{C} \mathrm{ha}^{-1}$ ) is converted to an ecosystem with a high $\mathrm{C}$ density, there is a net increase in $\mathrm{C}$ storage equal to the difference in $\mathrm{C}$ densities over a period equal to the time taken to reach the new state. Such conversions take place in southern Africa when grasslands or sparse savanna woodlands (low-C-density ecosystems) are afforested to produce pulpwood, mining timber, sawtimber, or fuelwood. The amount of $\mathrm{C}$ stored will depend on both the forest management practices (that is, species planted, espacement, thinning, and rotation length) and the bioclimatic region (Winjum et al., 1992).

Plantations are a common land use in Africa, but constitute only a small fraction of the land surface (1.2\% in South Africa, one of the most extensively planted African countries). They almost invariably consist of exotic (that is, non-African) species of fast-growing trees, generally drawn from the genera Pinus or Eucalyptus. Most of these plantations are managed on a rotational basis; when the growth rate of the trees begins to decline, they 
are clearfelled and another crop of trees is planted. Because of the favorable growing conditions in the tropics, the rotation length can range from 6 to 25 years, depending on the nature of the end product.

Even though the plantation is eventually felled, it nevertheless constitutes a net $\mathrm{C}$ storage if the mean $\mathrm{C}$ density over the rotation is greater than that of the vegetation it replaces. Furthermore, if any tree products are processed into a form where $\mathrm{C}$ is stored for a lengthy duration (for C-containing products of the fossil fuel industry, the Intergovernmental Panel on Climate Change considers a minimum life of 20 years), they constitute storage whether or not the forest area is expanding (or even if it is contracting, because in that case they must be subtracted from the $\mathrm{C}$ emission due to land use change).

The objective of this paper is to demonstrate, through the example of South Africa, the methods used to calculate $C$ storage from the activities of the plantation forestry industry.

\section{Materials and methods}

\subsection{Carbon Storage due to AfForestation}

In the absence of more locally specific data, the $\mathrm{C}$ density of plantations can be based on the published averages (for example, OECD, 1991; IPCC/OECD, 1994; UNEP et al., 1995). Most countries in which forestry is practiced will have data on final harvestable roundwood yields, which can be used to improve the default estimates. The total biomass of forests is about $50 \%$ greater than the mass of extractable timber at harvest because total biomass also includes branches, bark, leaves, and roots. Many tree species have been used in planation forests in South Africa. The softwood plantations are predominantly Pinus patula, while the hardwoods are predominantly Eucalyptus grandis. These two species have been taken as representative of all softwoods and hardwoods in South Africa, respectively.

The $\mathrm{C}$ densicy of the biomass standing crop can be calculated as

$$
C_{i}=V_{\text {stem }} \rho_{\text {wood }} F_{\text {carbon }} F_{\text {stem }}^{-1}
$$

where

$C=$ tree biomass $C$ density $\left(\mathrm{Mg} \mathrm{C} \mathrm{ha}^{-1}\right)$,

$V_{\text {stem }}=$ stem wood volume $\left(\mathrm{m}^{3} \mathrm{ha}^{-1}\right)$,

$\rho_{\text {wood }}=$ density of wood (the density of wet wood is $0.86 \mathrm{Mg} \mathrm{m}^{-3}$ for E. grandis and $0.88 \mathrm{Mg} \mathrm{m}^{-3}$ for P. patula; the moisture content of wood at harvest is $66 \%$ for $E$. grandis and $115 \%$ for P. patula (van Vuuren et al., 1978)),

$F_{\text {carbon }}=$ fraction of oven-dry mass that is $\mathrm{C}$ (assume 0.5 for all species), and

$F_{\text {stem }}=$ fraction that stemwood contributes to whole tree biomass ha-1 $(0.667$ for $E$. grandis and 0.704 for $P$. patula; see Table I).

Values for the $\mathrm{C}$ contents of plant tissues vary in the literature from $45 \%$ to $54 \%$ (Kinerson et al., 1977). A conversion factor of $50 \%$ is commonly used to estimate the organic C content of plant tissues (Brown and Lugo, 1982; Harmon et al., 1990). Table I 
TABLE I

Biomass components of $P$. patula and E. grandis in southern Africa at harvest maturity (Christie, 1991; Herbert and Robertson, 1991; Morris, 1992)

\begin{tabular}{lccc}
\hline & \multicolumn{3}{c}{ Percent of total dry biomass } \\
\cline { 2 - 4 } Component & 70.7 & \multicolumn{2}{c}{ Eucalyptus grandis } \\
\cline { 2 - 4 } \cline { 4 - 4 } Bole wood & 10.1 & 66.6 & 7 years \\
Branch wood & 5.9 & 9.4 & 75.2 \\
Bark & 1.5 & 7.5 & 2.7 \\
Leaves & 11.5 & 3.6 & 7.1 \\
Roots & & $(13.0)^{\mathrm{a}}$ & 2.3 \\
\hline
\end{tabular}

${ }^{\mathrm{a}}$ Root biomass was not measured but is estimated to constitute $15 \%$ of the total aboveground biomass.

presents the data used to estimate $F_{\text {stem }}$ for typical Pinus and Eucalyptus species growing in plantations in South Africa.

In South Africa, afforestation replaces montane grasslands, which have an aboveground biomass averaging $6 \mathrm{Mg} \mathrm{DM} \mathrm{ha}^{-1}$ (Everson et al., 1988). Assuming an equal amount of biomass belowground and 50\% C content, this converts to a C density of $6 \mathrm{Mg} \mathrm{C} \mathrm{ha}^{-1}$. The method as applied assumes that soil $\mathrm{C}$ is not affected by the land-use change. This is certainly not true, but there are insufficient data to make a generalization about the magnitude (or even the sign) of the changes.

Three methods are described below for calculating $\mathrm{C}$ storage by plantations. The first two are static methods that do not account for the history of afforestation, while the third (dynamic) method does.

\subsubsection{The static method using final carbon density}

This is the simplest approach, and is the default in the IPCC Guidelines for National Greenhouse Gas Inventories (UNEP et al., 1995). In essence, it credits the country with the full final biomass of the plantation on the date on which it is planted (about a decade or two before it actually accrues). This is not a serious source of error if the area planted annually is relatively constant and the trees are not harvested until some long time after they reach maturity. The calculation is as follows:

$$
\mathrm{C}_{s}=\sum_{j=1}^{m} \mathrm{~A}_{j}\left(\mathrm{C}_{p, j}-\mathrm{C}_{\mathrm{g}}\right),
$$


where

$C_{s}=$ total $\mathrm{C}$ stored $(\mathrm{Mg})$

$A_{j} \quad=\quad$ area planted per year of plantation type $j(\mathrm{ha})$,

$C_{p}=\mathrm{C}$ density at maturity of the plantation type $j\left(\mathrm{Mg} \mathrm{C} \mathrm{ha}^{-1}\right)$,

$C_{g} \quad=\quad \mathrm{C}$ density of the preceding land use $\left(\mathrm{Mg} \mathrm{C} \mathrm{ha}^{-1}\right)$, and

$m \quad=$ number of different plantation types (including different species and management regimes).

Table II presents the estimated $\mathrm{C}$ density at maturity for $P$. patula and $E$. grandis sawtimber and pulpwood management regimes for both coniferous and broadleafed forests. The area planted per year is obtained from national or regional statistics (Figure 1). Where it is highly variable, a 3- or 5-year average centered around the reference year should be used.

\subsubsection{The static method using mean carbon storage}

If the trees are harvested before or soon after they reach maturity, the mean carbon storage (MCS) method (Schroeder, 1992) is more appropriate than the peak biomass method described above. The MCS method determines the average amount of $\mathrm{C}$ on a site over a full rotation. It assumes that the plantation management system is sustainable and no yield reduction in the second and subsequent rotations. The calculation is made by summing

\section{TABLE II}

Carbon density at maturity in average South African plantations of $P$. patula and E. grandis under different management regimes (van Vuuren et al., 1978)

\begin{tabular}{|c|c|c|c|c|c|}
\hline Plantation type & $\begin{array}{c}\text { Rotation } \\
\text { length } \\
\text { (years) }\end{array}$ & $\begin{array}{l}\text { Final yield } \\
\left(\mathrm{m}^{3} \mathrm{ha}^{-1}\right)\end{array}$ & $\begin{array}{c}\text { Mean Annual } \\
\text { Increment } \\
\left(\mathrm{m}^{3} \mathrm{ha}^{-1} \mathrm{yr}\right)\end{array}$ & $\begin{array}{c}\text { Final C } \\
\text { density } \\
\left(\mathrm{Mg} \mathrm{C} \mathrm{ha}^{-1}\right)\end{array}$ & $\begin{array}{c}\text { Mean C } \\
\text { storage } \\
\left(\mathrm{Mg} \mathrm{C} \mathrm{ha-1)}^{-1}\right)\end{array}$ \\
\hline
\end{tabular}

\section{African coniferous}

forests (OECD 1991) 36.8-67.6

P. patula, sawtimber 25

P. patula, pulp

African broadleafed

forests (OECD, 1991) 72.8-117.0
E. grandis, sawtimber 25
695
E. grandis, pulp
10
122
(114-465)

59.2

31.7

"Aboveground biomass only.

Note: The Mean Average Increment (MAI) is determined at age 20 for sawtimber regimes and at rotation length for pulpwood. The MAI values used are the area-weighted means for South Africa (FOA, 1994). The final yields were from tables in Loveday and Kassier (1993); and the range is given in brackets. 


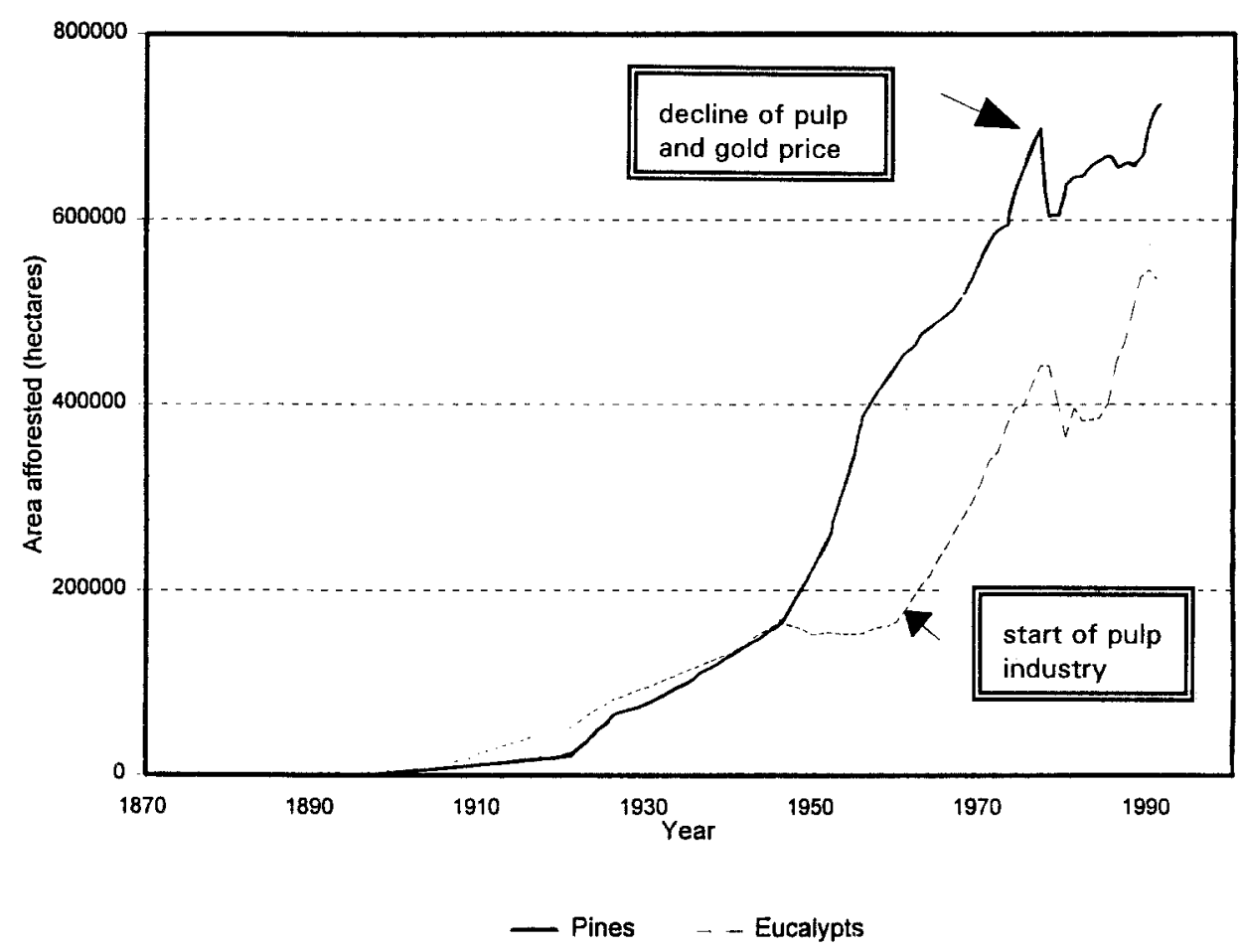

Figure 1. Cumulative afforested area in South Africa.

Sudden changes in the rates of afforestation can usually be ascribed to economic factors.

the $\mathrm{C}$ content of the standing crop for each year in the rotation and dividing by the rotation length.

$$
\mathrm{C}_{m}=n^{-1} \sum_{i=1}^{n} \mathrm{C}_{i}
$$

where

$C_{m}=$ mean $\mathrm{C}$ stored $\left(\mathrm{Mg} \mathrm{C} \mathrm{ha}^{-1}\right)$,

$C_{i}=\mathrm{C}$ density of the standing crop for year $i$ (the values are obtained from equations 6 and 7 ), and

$n=$ rotation length (years).

Table II also presents the $\mathrm{C}$ densities for $E$. grandis and $P$. patula calculated using the MCS method. Multiplying the mean $C$ density by the mean rate of afforestation for the respective species and management regimes is an improved static method estimate of $\mathrm{C}$ stored, because it allows for the fact that the plantations are harvested rotationally. 


$$
\mathrm{C}_{s}=\sum_{j=1}^{m} \mathrm{C}_{m, j} \mathrm{~A}_{m}
$$

where

$C_{\mathrm{s}} \quad=\quad$ total $\mathrm{C}$ stored $(\mathrm{Mg})$,

$C_{m, j}=$ mean $\mathrm{C}$ density for plantation type $j\left(\mathrm{Mg} \mathrm{C} \mathrm{ha}^{-1}\right)$, and

$A_{m}=$ mean rate of afforestation over a reference period.

\subsubsection{The dynamic method}

If the rate of afforestation varies greatly from year to year, the carbon density increment in a given reference year due to growth in that year must be tracked by each age-cohort of trees of each plantation type. This is known as a dynamic method.

$$
C_{s}=\left(\sum_{i=1, j=1}^{m, n} C_{i, j} A_{(r-i, j)}\right)-C_{g} A_{r}
$$

where

$C_{s, r}=\mathrm{C}$ stored in reference year $r(\mathrm{Mg} \mathrm{C})$,

$C_{i, j}=\mathrm{C}$ density of plantations of age $i$ and type $\mathrm{j}\left(\mathrm{Mg} \mathrm{Cha}^{-1}\right)$, and

$A_{r-i, j}=$ Area of type $j$ planted in year $r-i$ (ha).

The growth rate of a given cohort for a given year can be calculated using an empirical growth function that starts at close to zero on the date of planting and reaches a given final biomass at a specified harvest date. Examples of such functions, determined from forestry trial data in South Africa, are shown below.

Harrison et al. (1994) give the following result for $P$. patula in Nelshoogte, South Africa:

$$
V_{\text {stem }}=V_{\text {final }}(1-\exp (-0.1411(1-0.6782 \exp (-0.0013 T P)) i))^{3.0935}
$$

with $n=218, R^{2}=0.99$, and $S_{y, x}=44.72 \mathrm{~m}^{3}$.

Kotze (1991) gives the following result for E. grandis in Langepan, South Africa:

$$
V_{\text {stem }}=V_{\text {final }}(1-\exp (-(0.063471+0.0000089299 \mathrm{TP}) i))^{1.85873}
$$

with $n=86, R^{2}=0.94$, and $S_{y, x}=52.65 \mathrm{~m}^{3}$.

For these equations,

$V_{\text {stem }}=\quad$ Utilizable timber volume $\left(\mathrm{m}^{3} \mathrm{ha}^{-1}\right)$, and

$V_{\text {final }}=\quad$ Final stem volume $\left(\mathrm{m}^{3} \mathrm{ha}^{-1}\right)$ under optimal conditions (657.94 for $P$. patula and $274.79+41.7375 \times \mathrm{S}$ for $E$. grandis) in South Africa, where $S$ is the site index defined as the height reached after 10 years growth in pulpwood $(20 \mathrm{~m})$ or 20 years in saw wood $(30 \mathrm{~m})$.

$j=$ Stand age (years).

$T P \quad=\quad$ Surviving stems per hectare (for $P$. patula sawtimber is 1200 at planting, thinned to 650 at year 9,400 at year 14 , and 250 at year 19; for $E$. 
grandis sawtimber is 1,200 at planting, thinned to 750 at year 4,500 at year 7 , and 300 at year 10 . Pulpwood has no thinnings and commences at 1,200 ).

Although these functions are in volume units, they can be expressed in C density units by substituting for volume in Equation 1 (Figure 2).

\subsection{Carbon Storage In Timber Products}

Carbon storage in timber products is estimated by summing the $\mathrm{C}$ content of final forestry products have an expected life of more than 20 years. In South Africa most construction timber falls into this category, as well as timber destined to be permanently buried underground as mine supports. The $\mathrm{C}$ stored in timber products can be calculated as:

$$
\mathrm{C}_{p}=\sum_{k=1} V_{k} \rho_{k} \in_{k} F_{\text {carbon }}
$$

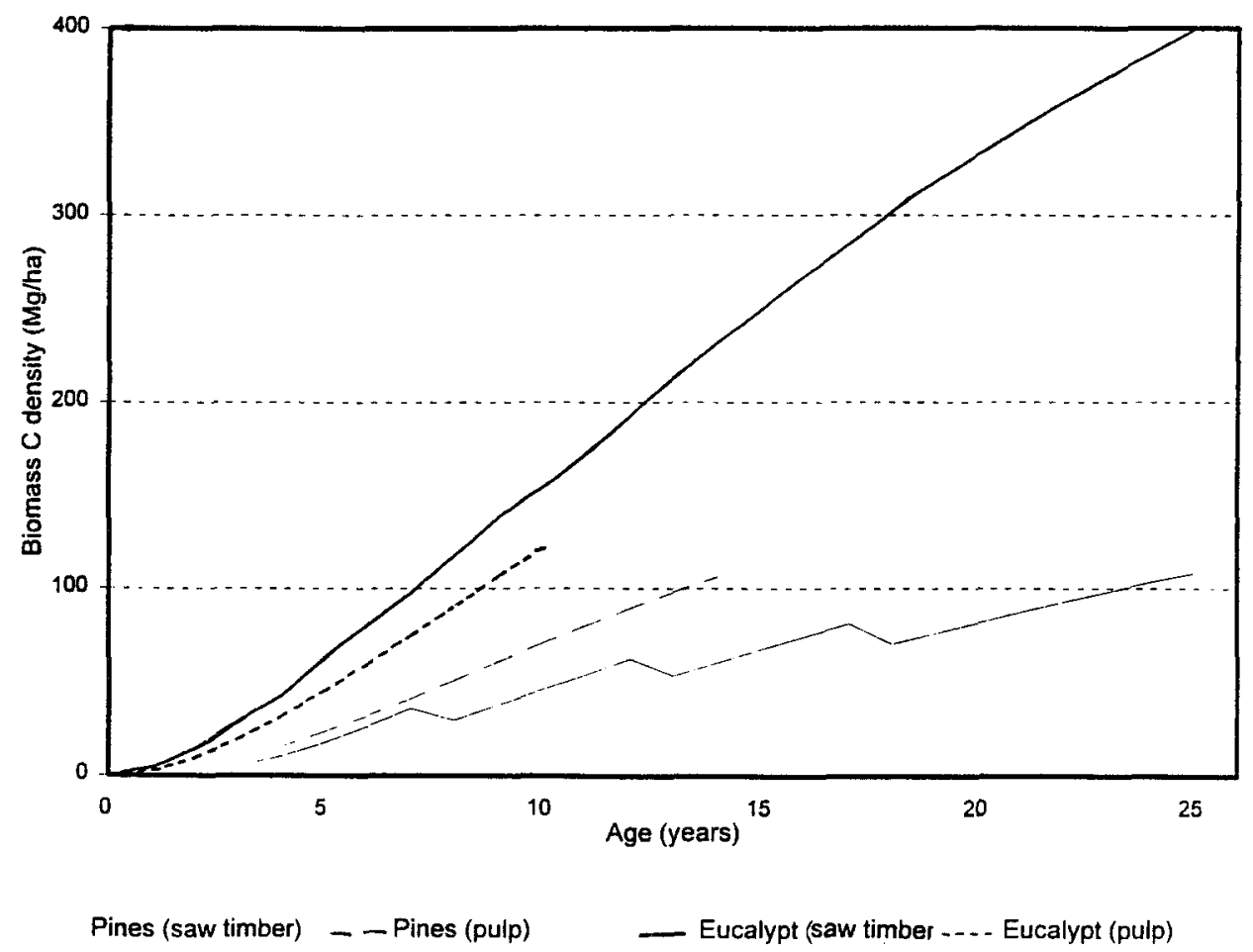

Figure 2. The biomass $\mathrm{C}$ density in the four main plantation types in South Africa. The dips in $\mathrm{C}$ density in the sawtimber plantations are due to thinning operations. 
where

$C_{p} \quad=\quad C$ stored in timber products $\left(\mathrm{Mg} \mathrm{yr}^{-1}\right)$,

$V_{k}=$ annual volume of roundwood timber used for product $k\left(\mathrm{~m}^{3} \mathrm{yr}^{-1}\right)$,

$\rho_{k}=$ density of air-dried timber product $k\left(\mathrm{Mg} \mathrm{m}^{-3}\right)$, and

$\grave{a}_{k} \quad=$ milling efficiency (fraction of roundwood that ends up in product $k$ ).

Estimates of the amount of $\mathrm{C}$ stored in sawtimber, board and panel products, and mining timber are given in Table III Volumes are obtained from LHA Management Consultants (LHA, 1993). If timber output is quoted on a volume basis, it must be converted to an oven-dry mass basis. The mean density at $10 \%$ moisture content (air dry) for $P$. patula is $0.45 \mathrm{Mg} \mathrm{m}^{-3}$ (range is $0.35-0.61$ ); for E. grandis it is $0.57 \mathrm{Mg} \mathrm{m}^{-3}$ (range is $0.5-0.8$ ). If the product data are quoted as roundwood (that is, unsawn logs), they must be reduced according to the milling efficiency (the ratio of the mass of sawn timber to input roundwood is 46 to $55 \%$ for pine and 26 to $30 \%$ for eucalyptus). The milling efficiency for mining timber is estimated at $80 \%$. In general, wood-based products have a $\mathrm{C}$ content of $50 \%$ by mass. It is assumed that sawmill residue is generally burnt, and therefore $\mathrm{C}$ is not stored. However, this is not strictly true, as increasingly large amounts of waste from sawmills are utilized in the board and panel manufacturing sector.

\section{Results and discussion}

The time series of afforestation in South Africa is illustrated in Figure 1. Wattle (principally Acacia mearnsii) was formerly extensively planted but now comprises less than $10 \%$ of the afforested area and $6 \%$ of new plantings. The impact of economic conditions on the rate of afforestation is clear. The increase in planted area is likely to continue, but ultimately will be limited by environmental and water-use considerations.

Table IV summarizes the forestry $\mathrm{C}$ storage calculations for South Africa using different methods. The simplest static approach, which uses the peak biomass to calculate the $\mathrm{C}$

TABLE III

Carbon storage in long-lived (20-plus years) timber products

\begin{tabular}{|c|c|c|c|c|c|}
\hline Product & $\begin{array}{l}\text { Volume of } \\
\text { roundwood used } \\
\left(\times 10^{6} \mathrm{~m}^{3}\right)\end{array}$ & $\begin{array}{l}\text { Oven-dry } \\
\text { density } \\
\left(\mathrm{Mg} \mathrm{m}^{3}\right)\end{array}$ & $\begin{array}{c}\text { Moisture content } \\
\text { of roundwood } \\
\text { (\% of air dry mass) }\end{array}$ & $\begin{array}{l}\text { Milling } \\
\text { efficiency } \\
(\%)\end{array}$ & $\begin{array}{c}\text { C stored } \\
\left(\mathrm{Tg} C \mathrm{y}^{-1}\right)\end{array}$ \\
\hline P. patula, sawn timber & 3.80 & 0.45 & 115 & 50 & 0.39 \\
\hline E. grandis, sawn timber & 0.05 & 0.57 & 66 & 28 & 0.05 \\
\hline Boards and panels & 0.13 & 一 & - & 100 & 0.13 \\
\hline Mine supports & 2.60 & 0.57 & 80 & 0.58 & \\
\hline Total & 1.15 & & & & \\
\hline
\end{tabular}


TABLE IV

Carbon storage in 1990 in $P$. patula and E. grandis plantations ( $\mathrm{Tg} \mathrm{C} \mathrm{y} \mathrm{y}^{-1}$ ) growing under sawtimber and pulpwood regimes, calculated using different methods

\begin{tabular}{lccc}
\hline & \multicolumn{2}{c}{ Static methods } & Mean C storage \\
Plantation type & Tg C & $\begin{array}{c}\text { Dynamic } \\
\text { method }\end{array}$ \\
\hline & & & 0.08 \\
P. patula, sawtimber & 0.14 & 0.11 & 0.14 \\
P. patula, pulpwood & 0.55 & 0.44 & 0.85 \\
E. grandis, sawtimber & 1.16 & 0.59 & 1.47 \\
E. grandis, pulpwood & 0.87 & 0.44 & 2.54 \\
Total & 2.72 & 1.58 & \\
\hline
\end{tabular}

Note: For static methods, the area of new afforestation was 11420 ha of pines and 22700 ha of eucalyptus. It was assumed that $19 \%$ of both was destined for sawwood and $81 \%$ for pulp.

density, overestimates $\mathrm{C}$ storage in rotational plantations by a factor of nearly two relative to the static method using MCS (Winjum et al., 1992).

The dynamic method is most appropriate for situations (such as in South Africa) where the rate of afforestation varies over time. The static MCS method underestimates $\mathrm{C}$ storage in South Africa by $37 \%$, because the current rate of afforestation is less than it was during the last decade. The similarity of the estimates by the static peak $\mathrm{C}$ density method and the dynamic method is purely coincidental.

The calculations outlined above do not allow for changes in $\mathrm{C}$ density other than changes due to an increase in biomass. It is more than likely that the $\mathrm{C}$ stored in soil organic matter also changes. Soil $\mathrm{C}$ is often assumed to be higher under forests than under grasslands, but this is not necessarily true; grasses translocate a much larger fraction of their $\mathrm{C}$ belowground than forests do. On the other hand, the amount of $\mathrm{C}$ stored on the surface of the soil as litter can be large in forests, especially under pine plantations. In the Eastern Transvaal of South Africa, the litter accumulation can reach $150 \mathrm{Mg} \mathrm{DM} \mathrm{ha}^{-1}$, or about half of the stem biomass. However, until there are more reliable data on the magnitude of soil and litter $\mathrm{C}$ pools in tropical plantations, it is conservative to ignore them in the calculations.

The $\mathrm{C}$ stored in various long-lived timber products is given in Table III. The amount of $\mathrm{C}$ stored in these products is comparable to that stored in biomass. The default assumption in the IPCC Guidelines for National Greenhouse Gas Inventories (UNEP et al., 1995) is that timber products are merely replacing existing timber products that are decaying or burned, and therefore should not be considered a net storage. However, in rapidly growing and urbanizing countries such as South Africa, the national pool of timber is increasing. Most sawn timber and board products are used for construction in South Africa, so it is reasonable to expect them to have a long life. The mining support timber 
is left underground when the mines are abandoned, and can therefore be considered to be securely stored $\mathrm{C}$.

It is unclear how to consider paper pulp for emission inventory purposes, because it is a partially stored product. Although most paper products have a relatively short life (less than 5 years), a large fraction of these disposable products is recycled in some countries (31\% in South Africa in 1992 (Gerischer, 1993). Much of the paper that is not recycled ends up in landfills, where it may have a long life. However, only a fraction of the pulp produced in South Africa is used locally.

The forest industry stores a total of $3.69 \mathrm{Tg} \mathrm{C} \mathrm{yr}^{-1}$, which is equivalent to $13.5 \mathrm{Tg} \mathrm{CO}_{2}$, or about $3.8 \%$ of the annual $\mathrm{CO}_{2}$ emissions for South Africa. Although not insignificant, this amount is too small to make a serious impact on the national emission budget. The potential for increasing $\mathrm{C}$ storage via this avenue in South Africa is very small because of the adverse environmental impacts of further plantations and the limited area that is bioclimatically suitable for afforestation (Winjum et al., 1993). The potential in wetter African countries is greater, but only if the plantations are established in areas with a low existing $\mathrm{C}$ density. The clearing of endemic woodlands for replacement with pines and eucalypts will not necessarily meet this criterion.

\section{Conclusions}

The methods for calculating $\mathrm{C}$ sequestration through afforestation are relatively simple to apply, but obtaining reliable data on biomass $\mathrm{C}$ densities and rates of afforestation may be difficult in some countries. Data on nontimber biomass fractions, especially belowground, are generally sparse. The $\mathrm{C}$ density and growth data used in this analysis for South Africa are applicable for all of southern Africa.

The use of peak biomass for the calculation of $\mathrm{C}$ density is not appropriate for rotation forestry. A mean $\mathrm{C}$ storage approach, which averages the $\mathrm{C}$ density over the rotation, is recommended (Winjum et al., 1992; Winjum et al., 1993). The dynamic method of C storage calculation, which accounts for the age of various plantations, is recommended where the rate of afforestation varies between years.

Storage of $\mathrm{C}$ in long-lived forest products is as important as new afforestation as a $\mathrm{C}$ sink in countries where the national pool of timber products is growing, and should be considered as part of the emission inventory. Additional research is needed on changes in $\mathrm{C}$ storage in the soil and litter layers and the fate of paper products.

\section{References}

Christie, S.I.: 1991, The Biomass Production of Eucalyptus grandis Planted at Various Close Spacings, FORDEA 288, Division of Forest Science, CSIR, Pretoria.

Brown, S., and Lugo, A.E.: 1982, The storage and production of organic matter in tropical forests and their role in the global carbon cycle, Biotropica, 14, 161-187.

Dixon, R.K., Winjum, J.K., Andrasko, K.J., Lee, J.L., and Schroeder, P.E.: 1994, Integrated land use systems: assessment of promising agroforest and alternative land use practices to enhance carbon conservation and sequestration, Climatic Change, 27, 71-92. 
Everson, T.M., van Wilgen, B.W., and Everson, C.S.: 1988, Adaptation of a model for rating fire danger in the Natal Drakensberg, South African Journal of Science, 84, 44-49.

FOA (Forest Owner's Association): 1994, South African Forestry Facts, Forest Owner's Association, Rivonia, South Africa.

Gerischer, G.F.R: 1993, Pulp and paper manufacture in South Africa, in: van der Sijde, H.A. (ed.), Forestry Handbook, The South African Institute of Forestry, Pretoria, 498-519.

Harmon, M.E., Ferrell, W.K., and Franklin, J.F.: 1990, Effects of carbon storage of conversion old-growth forests to young forests, Science, 240, 699-702.

Harrison, W.M., Pienaar, L.V., and Kotze, H.: 1994, Planting Density Effects on Growth and Yield in the Nelshoogte Correlated Curve Trend Experiment with Pinus patula, CSIR report no. FOR-C-264, 71 pages,

Herbert, M.A., and Robertson, M.A.: 1991, Nutrient Distribution, Cycling and Loss Within Stands of Commercial Timber Species, Annual Research Report, Institute for Commercial Forestry Research, Pietermaritzburg, South Africa, 54-59.

IPCC/OECD (Intergovernmental Panel on Climate Change/Organisation for Economic Co-operation and Development) Joint Programme: 1994, IPCC Draft Guidelines for National Greenhouse Gas Inventories, IPCC/OECD Joint Programme, Paris, 3 volumes.

Kinerson, R.S., Ralston, C.W., and Wells, C.G., 1977, Carbon cycling in a loblolly pine plantation, Oecologica, 29, 1-10.

Kotze, H.: 1991, Growth and Yield Prediction Methodologies-An Implementation of Different Strategies, forest management seminar, Univ. Stellenbosch, 29 pages.

Loveday, N.C., and Kassier, H.W.: 1993, Yield tables for some of the major timber species grown in South Africa, in van der Sijde, H.A. (ed.), Forestry Handbook, The South African Institute of Forestry, Pretoria, 303-323.

LHA Management Consultants: 1993, The Current and Forecast Demand for Roundwood in South Africa, report to SATGA, Pretoria.

Morris, A.R.: 1992, Dry matter and nutrients in the biomass of an age series of Pinus patula plantations in the Usutu forest, Swaziland, SA Forestry Journal, 163, 5-11.

OECD (Organisation for Economic Co-operation and Development): 1991, Estimation of Greenhouse Gas Emissions and Sinks, Organisation of Economic Cooperation and Development, Paris.

Schroeder, P.E.: 1992, Carbon storage potential of short rotation tropical tree plantations, Forest Ecology and Management, 50, p 31-41.

UNEP, OECD, IEA, IPCC (United Nations Environment Programme, Organisation for Economic Cooperation and Development, International Energy Agency, Intergovernmental Panel on Climate Change): 1995, IPCC Guidelines for National Greenhouse Gas Inventories, IPCC, Bracknell, 3 Volumes.

van Vuuren, N.J.J., Banks, C.H., and Stohr, H.P.: 1978, Shrinkage and Density of Timbers Used in the Republic of South Africa, Bulletin 57, Department of Forestry, Pretoria.

Winjum, J.K., Dixon, R.K., and Schroeder, P.E.: 1992, Estimating the global potential of forest and agroforest management practices to sequester carbon, Water, Air and Soil Pollution, 64, 213-227.

Winjum, J.K., Dixon, R.K., and Schroeder, P.E.: 1993, Forest management and carbon storage: an analysis of 12 key forest nations, Water, Air and Soil Pollution, 70, 239-257. 